\title{
Effects of Varying Essential Oil Mixture Concentrations Applied Underconditions of Different Temperature Stress on Cardiac Markers and Other Blood Parameters
}

Original Article

mAuthor(s)

Bayraktar B' (iD https://orcid.org/0000-0002-2335-9089 Tekce E" (iD https://orcid.org/0000-0002-6690-725X

Faculty of Health Sciences, Bayburt University, Bayburt 69000, Turkey.

Faculty of Applied Sciences, Bayburt University, Bayburt 69000, Turkey.

\section{ABSTRACT}

Cardiac troponin (cTnl) and erythrocyte distribution width (RDW) have been used as specific markers for the evaluation of cardiac arrhythmias and myocardial diseases. In this experimental study, we aimed to determine the dose-dependent administration of an Essential OilMixture (EOM) (Eucalyptus globulusLabill, Thymus vulgaris, Cymbopogon nardus, and Syzygiumaromaticum) on the serum erythrocyte indices and myocardial damage. We used 400 male, oneday-old, Ross-308 chicks. Each group $\left((\mathrm{n}=8)\left(22^{\circ} \mathrm{C}\right.\right.$ Control (C), $\mathrm{C}+250$ $\mathrm{mL} / 1,000 \mathrm{~L}, \mathrm{C}+500 \mathrm{~mL} / 1,000 \mathrm{~L}, \mathrm{C}+750 \mathrm{~mL} / 1,000 \mathrm{~L}$ ), $36^{\circ} \mathrm{C}$ (stress control (SC), SC+250 mL/1,000 L, SC+500 mL/1,000 L, SC+750 mL/1,000 L) was further divided into eight groups with 50 animals. Each group of 50 chicks was further subdivided into five groups with 10 animals in each compartment. The results showed that the WBC, RBC, HGB, HCT, RDW$\mathrm{SD}, \mathrm{RDW}-\mathrm{CV}$, and Lymphocyte decreased in groups without exposure to temperature stress $\left(22^{\circ} \mathrm{C}\right)$ compared to the $22^{\circ} \mathrm{C}$ control group; whereas, CnTnl, MCHC, NEUT, and IG $(p<0.05)$ increased compared to the control group. In groups exposed to temperature stress $\left(36^{\circ} \mathrm{C}\right)$, the WBC, HGB, HCT, RDW-SD, and Lymphocyte decreased compared to the control group, but MCH, MCHC, NEUT, and IG increased compared to the control. However, CTnl, CK, creatinine, RBC, and RDW had no effect on $C D, M O N O, E O$, and BASO $(p<0.05)$. EOM mixture had no effect on hematological and biochemical parameters.

\section{INTRODUCTION}

In recent years, there have been various global developments In order to improve product quantity and quality in line with the wishes of Consumers to meet the enhanced nutritional needs of the rapidly growing world population. However, fattening performance is significantly affected by heat stress in broiler hens owing to global warming. Broilers have a higher basal metabolic rate, as they have a high rate of feed utilization as a genetic characteristic (Mohamed et al., 2012; Mahmoud et al., 2015). Given the rapid development of and stress exposure in broilers and the sudden death syndrome associated with cardiovascular diseases due to lubrication in internal organs, broilers breeding facilities are associated with high mortality. Studies have shown that the mortality rate is doubled in birds fed high-protein diets (Breeding et al., 1994; England et al., 2017). Cardiomyopathies are diseases of the heart muscle that result from heart failure and cause cardiac dysfunction. The disease has a high morbidity and mortality rate and results in sudden death. Cardiomyopathies are associated with decreased diastolic volume especially in the ventricles, a dilated atrium, limited ventricular filling and rarely, ventricular myocardial fibrosis. In this case, fat accumulation is caused by the prevention of electrical 
conduction and arrhythmias (Maron et al., 2006; Wieczorek et al., 2008; Wexler et al., 2009; England et al., 2017).

Cardiac troponin (cTnl) is an important protein that contributes to the regulation of actin-myosin, which is an essential component of striated-muscle contraction. Troponin has three basic globular (Tnl, TnT, and TnC) proteins on striated muscles. These proteins contribute to tropomyosin-troponin binding (troponin-T), actinmyosin contraction by regulating actin and myosin (troponin-I), or by binding calcium in the troponin structure by inhibiting actomyosin ATPase activity (O'Brien et al., 2006; Kamely et al., 2019). Circulating cTnl has recently been recognized as a biomarker by the American College of Cardiology for the diagnosis of cardiomyocyte damage and acute coronary syndromes (O'Brien, 2008; Kusumoto et al., 2012; Sato et al., 2012; Kamely et al., 2019). The amount of cardiac troponin in all organisms depends on the type, duration, and degree of myocyte injury (Alpert et al., 2000). Studies have reported that acute right heart failure due to myocardial damage significantly increases serum troponin T levels in broilers (Maxwell et al., 1995).

One of the prognostic markers of cardiovascular disease is the red cell distribution width (RDW). The effect of RDW on mortality is frequently evaluated, and it has been shown that increased RDW level is an independent and strong risk factor for mortality in cardiovascular diseases (Salvagno et al., 2015; Muhlestein et al., 2016). RDW increase is associated with chronic inflammation and increased oxidative stress (Ferrucci et al., 2005).

Anaemia, on the other hand, is an important precursor of cardiovascular disease. One of the indicators of anaemia is the erythrocyte index (Metivier et al., 2000). These enzymes are considered reliable indicators of heat stress damage in chicken myocardial cells (Saravanan et al., 2013; Tang et al., 2013; Wu et al., 2015). Cardiovascular problems are understood to be an important cause of sudden death in broilers (Summers, 2013). Flip-over disease (sudden death syndrome), which is seen in poultry aged 2-42 days, is a syndrome that causes severe economic losses in the broiler production industry. Antibiotics were used until 2006 to prevent these problems, but the World Health Organization subsequently stated that microorganisms gained resistance to antibiotics and could pose a risk to human health because of the animal rations under the treatment dosage (Yörük et al., 2008; Çetin, 2012; Habrun et al., 2012; Tekce \& Mehmet, 2016). In this context, various products have been researched as feed additives to animal feeds. Research is one of the most subject of medical aromatic plants. These plants are generally characterized by secondary metabolites such as alkaloids, glycosides, and resins. These metabolites contain compounds that do not carry the risk of accumulation in animals and humans orthe ability to gain resistance to microorganisms (Burt, 2004; Feizi et al., 2013). In our study, we used the essential oil mixture (EOM; Eucalyptus globulusLabill., Thymus vulgaris, Cymbopogon nardus, and Syzygiumaromaticum) used in previous studies on monogastric animals (Botsoglou et al., 2004; Dezsi et al. , 2015), as well as anti-microbial (Daroui-Mokaddem et al., 2010), anti-inflammatory (Guimarães \& Quintans-Júnior, 2013), anti-viral (Silva \& Pessoa, 2011), anti-fungal (Al-Ja'fari et al., 2011), anti-parasitic (Kpoviessi et al., 2014; Monzote et al., 2007) and no side effects on blood parameters (Tekce \& Gül, 2017).

This study investigated the effects ofthe abovementioned EOM on someblood parameters and cardiac markers when added at different concentrationsto the drinking water of temperature-stressed broilers (exposed to $22^{\circ} \mathrm{C}$ and $36^{\circ} \mathrm{C}$, respectively). With regards to the measurement of temperature stress and EOM, circulating cardiac troponin-I (cTnl) and erythrocyte indices including RDW-CV, RDW-SD MCV, MCH, $\mathrm{MCHC}, \mathrm{Hb}$, and $\mathrm{HCT}$ values were investigated.

\section{MATERIALS AND METHODS}

\section{Animals, Experimental Design, Feeds}

We included 400 male, one-day-old, Ross-308 chicks. The research was carried out at Bayburt University Food, Agriculture and Livestock Application and Research Centre Unit and lasted 42 days with a 35-day fattening period. During the trial, the animals were separated in 10 animals in each group with the dimensions of $110 \times 110 \times 100 \mathrm{~cm}$ for each group in the winged unit.At the end of the 7-day training period, the study groups were composed of 8 groups $\left(22^{\circ} \mathrm{C}\right.$ Control (C), C+250 mL/1,000 L, C+500 mL/1,000 L, $\mathrm{C}+750 \mathrm{~mL} / 1,000 \mathrm{~L}$ ), $36^{\circ} \mathrm{C}$ (stress control (SC), SC+250 $\mathrm{mL} 1,000 \mathrm{~L}, \mathrm{SC}+500 \mathrm{~mL} / 1,000 \mathrm{~L}, \mathrm{SC}+750 \mathrm{~mL} / 1,000$ L) of 50 animals each with equal body weight. The treatment groups were as follows: $22^{\circ} \mathrm{C}$ stress-free group (Control; EOM-250; EOM-500; EOM-750); and $36^{\circ} \mathrm{C}$ stress-applied volatile oil mixture(SK, SEOM-250, SEOM-500, and SEOM-750) -250, SEOM-500, and SEOM-750. Each group was divided into five subgroups 
with 10 chicks each. Three different basal chick feeds and nutrient composition of the feeds are given in Table 1. This study was conducted in accordance with the ethical principles and guidelines while ensuring the protection of animal welfare and rights. The ethics committee of Atatürk University Veterinary Faculty (22.02.2018/2/24) approved this study.

\section{Poultry House Heat Moisture and Illumination}

While broiler chicks are given water ad libitum, the ration content used in their nutrition is given in Table 1.
Feed and EOM were added to thewater to the working groups at the same time every day. Analysis of the feeds given to the animals was carried out according to the methods described in A.O.A.C (AOAC, 2005). During the training period, the lighting applied to the chicks was 24 hours $(60 \mathrm{~W})$ and the heating was $0-2$. 2-5.day, at $27-28^{\circ} \mathrm{C}$ temperature.

\section{Contents of the EOM Mixture}

During the study, broiler EOM mixture was added to the drinking water provided from a commercial

Table 1 - Basal diet ration nutrient content and analyzes $(\mathrm{g} / \mathrm{kg})$.

\begin{tabular}{lccc}
\hline Raw Material & Starter $(0-14 \mathrm{~d})$ & Grower $(14-28 \mathrm{~d})$ & Finisher $(28-42 \mathrm{~d})$ \\
\hline Maize & 52.70 & 54.60 & 58.12 \\
Maize gluten feed & 15.21 & 21.20 & 26.14 \\
Soybean residue & 26.35 & 18.90 & 10.65 \\
Di-calcium phosphate & 1.95 & 1.70 & 1.60 \\
Calcium carbonate & 1.18 & 1.10 & 1.04 \\
Sodium chloride & 0.31 & 0.31 & 0.31 \\
Sodium bicarbonate & 0.20 & 0.20 & 0.20 \\
Salt & 0.2 & 0.2 & 0.2 \\
Methionine & 0.50 & 0.50 & 0.44 \\
Lysine & 1.20 & 1.10 & 1.10 \\
Vitamin-mineral premix ${ }^{1}$ & 0.20 & 0.20 & 0.20 \\
\hline ME (kcal/ kg) & 3100 & 3150 & 3225 \\
Crude protein (\%) & 24 & 22 & 20 \\
Crude oil (\%) & 2.61 & 2.30 & 2.50 \\
Ash (\%) & 5.19 & 4.63 & 3.85 \\
Moisture (\%) & 13.20 & 13.20 & 13.20 \\
\hline
\end{tabular}

Vitamin-mineral premix içeriği (per kg of diet): vitamin A, $12000 \mathrm{IU}$; vitamin D3, $1500 \mathrm{lU}$; vitamin E, $35 \mathrm{mg} / \mathrm{kg}$; vitamin K3, $5 \mathrm{mg} / \mathrm{kg}$; vitamin B1, $3 \mathrm{mg}$; vitamin B2, $4 \mathrm{mg}$; vitamin B6, 4 mg; vitamin B12, 0.03 mg; calcium -D-pantothenate, 15 mg; folic acit, 1 mg; niacin, 25 mg; D-biotin, 0.115 mg; Mg 80 mg/kg; I, 0,15 mg/kg; Co, 0.2 mg/kg; Cu, 5 mg/kg; Fe, 60 $\mathrm{mg} / \mathrm{kg} ; \mathrm{Se}, 1 \mathrm{mg} / \mathrm{kg} ; \mathrm{Zn}, 60 \mathrm{mg} / \mathrm{kg}$.

company (Ankara, Turkey). The mixture was analyzed by GC (Gas Chromatography) in Bayburt University Central Research Laboratories. The content of the essential oil mixture was 26,70\% Durenol, 23,89\% Eugenol, 16,49\% Gamma terpinene, 8,35\% Hieptaethylene glycol, 6,42\% Hexaethylene glycol, 3,31\% Cymene, 3,08\% Pentaethylene glycol, 2,87\% Caryophyllene, 2,30\% D-Limonene, 2,18\% Betapinene and 0,95\% Eucalyptol.

\section{Collection of Serum Samples}

At the end of the trial, 10 animals randomly selected from each group and 80 animals in total were categorized by $10 \mathrm{ml}$ blood extraction to perform biochemical blood analysis during cervical dislocation. The refrigerated blood from the animals centrifuged (NF 1200, CORE, Ankara, Turkey) for 12 minutes at+4 ${ }^{\circ} \mathrm{C}$ to obtain serum samples in eppendorf tubes.

\section{Measurement of Serum Cardiac Troponin (cTnl) level}

Serum cTnl (cTnl, Sunred, Product code: 20116-0007, China) ELISA kits, which are commercially available for the measurement of cTnl levels in blood serum samples, were obtained as a result of the study. Assay (ELISA) was evaluated by reading the absorbance values at $450 \mathrm{~nm}$ wave length.

\section{Statistical analysis}

The measures were all normally distributed and data are expressed as means and standard errors of the mean. Univariate general linear model was used to identify the differences existing in four diet groups. Duncan multiple comparison tests were applied in order to compare differences between the means. All statistical tests were performed at $5 \%$ level of statistical significance by IBM SPSS statistics 20.0 


\section{RESULTS}

The effects of varying EOM concentrations (250, 500, and $750 \mathrm{~mL} 1000$ L)added to the broilers' drinking water and fed under conditions of different temperature stress $\left(22^{\circ} \mathrm{C}\right.$ and $\left.36^{\circ} \mathrm{C}\right)$ on haematological and cTnl effects are analysed in Tables 2, 3, and 4 . In the groups that are not exposed to heat stress $\left(22^{\circ} \mathrm{C}\right), \mathrm{WBC}$, RBC, HGB,HCT, RDW-SD, RDW-CV and Lymphocyte decreased compared to the control group, whereas cnntn-1, MCHC, neut and IG increased compared to the control group, CK, creatine, $\mathrm{MCV}, \mathrm{MCH}$, Mono, EO and Baso, and it has no effect on CK, creatine, MCV, $\mathrm{MCH}$, mono, and Baso $(p<0.05)$. In the groups exposed to a temperature stress of $36^{\circ} \mathrm{C}$, the WBC, HGB, HCT, RDW-SD, and Lymphocyte decreased compared to the the control group, increased compared to $\mathrm{MCH}$, MCHC, neut and IG, but had no effect on Serum CTnl, CK, creatinine, RBC, RDW-CD CD, MONO, EO and BASO $(p<0.05)$.

Table 2 - The effects of EOM added to the drinking water of groups fed in stress conditions on biochemical blood parameters.

\begin{tabular}{|c|c|c|c|c|c|c|c|c|c|c|c|c|}
\hline & \multicolumn{2}{|c|}{ CK } & \multicolumn{2}{|c|}{ RDW-SD } & \multicolumn{2}{|c|}{ RDW-CV } & \multicolumn{2}{|c|}{ PCT } & \multicolumn{2}{|c|}{ WBC } & \multicolumn{2}{|c|}{ CnTn-1 } \\
\hline & $22^{\circ} \mathrm{C}$ & $36^{\circ} \mathrm{C}$ & $22{ }^{\circ} \mathrm{C}$ & $36^{\circ} \mathrm{C}$ & $22^{\circ} \mathrm{C}$ & $36^{\circ} \mathrm{C}$ & $22^{\circ} \mathrm{C}$ & $36^{\circ} \mathrm{C}$ & $22^{\circ} \mathrm{C}$ & $36^{\circ} \mathrm{C}$ & $22{ }^{\circ} \mathrm{C}$ & $36^{\circ} \mathrm{C}$ \\
\hline Control & 5751.6 & 7259.6 & 47.80 & 48.57 & 10.90 & 11.12 & 0.00 & 0.00 & $339.76^{a}$ & $283.18^{a}$ & $0.25^{b}$ & 0.75 \\
\hline EOM $250 \mathrm{ml} / \mathrm{l}$ & 4931.0 & 5008.8 & 46.90 & 40.05 & 10.96 & 9.35 & 0.00 & 0.00 & $8.87^{b}$ & $67.84^{b}$ & $0.38^{b}$ & 0.73 \\
\hline EOM $500 \mathrm{ml} / \mathrm{l}$ & 5397.6 & 6099.0 & 40.33 & 45.20 & 9.50 & 10.26 & 0.00 & 0.00 & $69.03^{c}$ & $54.83^{b}$ & $0.56^{a}$ & 0.77 \\
\hline EOM $750 \mathrm{ml} / \mathrm{l}$ & 5976.2 & 5626.2 & 38.63 & 44.00 & 8.86 & 10.03 & 0.00 & 0.00 & $58.01^{d}$ & $55.90^{\mathrm{b}}$ & $0.43^{\mathrm{ab}}$ & 0.79 \\
\hline \multicolumn{13}{|c|}{ Source of variation ( $p$ values) } \\
\hline Diet & \multicolumn{2}{|c|}{0.53} & \multicolumn{2}{|c|}{0.02} & \multicolumn{2}{|c|}{0.06} & \multicolumn{2}{|c|}{0.00} & \multicolumn{2}{|c|}{0.00} & \multicolumn{2}{|c|}{0.00} \\
\hline Temperature & \multicolumn{2}{|c|}{0.51} & \multicolumn{2}{|c|}{0.50} & \multicolumn{2}{|c|}{0.74} & \multicolumn{2}{|c|}{0.00} & \multicolumn{2}{|c|}{0.00} & \multicolumn{2}{|c|}{0.00} \\
\hline Temperature $\mathrm{x}$ Diet & \multicolumn{2}{|c|}{0.82} & \multicolumn{2}{|c|}{0.06} & \multicolumn{2}{|c|}{0.15} & \multicolumn{2}{|c|}{0.00} & \multicolumn{2}{|c|}{0.03} & \multicolumn{2}{|c|}{0.00} \\
\hline \multicolumn{13}{|c|}{ Main effect means diet } \\
\hline Control & \multicolumn{2}{|c|}{6505.6} & \multicolumn{2}{|c|}{$48.18^{a}$} & \multicolumn{2}{|c|}{$11.01^{\mathrm{a}}$} & \multicolumn{2}{|c|}{0.00} & \multicolumn{2}{|c|}{$311.47^{a}$} & \multicolumn{2}{|c|}{$0.50^{\mathrm{b}}$} \\
\hline EOM $250 \mathrm{ml} / \mathrm{l}$ & \multicolumn{2}{|c|}{4969.9} & & & & & & & & & & \\
\hline EOM $500 \mathrm{ml} / \mathrm{l}$ & 57 & & & & & & & & & & & \\
\hline EOM $750 \mathrm{ml} / \mathrm{l}$ & 580 & & & & & & & & & & & \\
\hline Temperature & & & & & & & & & & & & \\
\hline $22^{\circ} \mathrm{C}$ & & & & & & & & & & & & \\
\hline $36^{\circ} \mathrm{C}$ & 59 & & 44 & & & & & & & & & \\
\hline SEM & 51 & & & & & & & & & & & \\
\hline
\end{tabular}

$a, b, c:$ Means with the same letters in a column are statistically equal $(p>0.05)$. Creatine Kinase (CK), Red Cell Distribution Width-Standard Deviation (RDW-SD), Red Cell Distribution Width-Coefficent of Variation (RDW-CV), Prokalsitonin (PCT), White Blood Cell (WBC), Cardiac troponin $1\left(C_{n} T_{n}-1\right)$.

Table 3 - The effects of EOM added to the drinking water of groups fed in stress conditions on biochemical blood parameters.

\begin{tabular}{|c|c|c|c|c|c|c|c|c|c|c|c|c|c|c|}
\hline & \multicolumn{2}{|l|}{ RBC } & \multicolumn{2}{|l|}{$\mathrm{HGB}$} & \multicolumn{2}{|l|}{ HCT } & \multicolumn{2}{|c|}{ KREATIN } & \multicolumn{2}{|l|}{ NRBC } & \multicolumn{2}{|l|}{ NEUT } & \multicolumn{2}{|l|}{ LYMPH } \\
\hline & $22^{\circ} \mathrm{C}$ & $36^{\circ} \mathrm{C}$ & $22^{\circ} \mathrm{C}$ & $36^{\circ} \mathrm{C}$ & $22^{\circ} \mathrm{C}$ & $36^{\circ} \mathrm{C}$ & $22^{\circ} \mathrm{C}$ & $36^{\circ} \mathrm{C}$ & $22^{\circ} \mathrm{C}$ & $36^{\circ} \mathrm{C}$ & $22^{\circ} \mathrm{C}$ & $36^{\circ} \mathrm{C}$ & $22^{\circ} \mathrm{C}$ & $36^{\circ} \mathrm{C}$ \\
\hline Control & 2.88 & 2.63 & 7.83 & 7.32 & 35.90 & 32.47 & 0.00 & 0.00 & 0.00 & 0.00 & 5.32 & 7.34 & 334.68 & 275.78 \\
\hline EOM $250 \mathrm{ml} / \mathrm{l}$ & 2.66 & 2.53 & 7.16 & 6.85 & 32.13 & 30.05 & 0.00 & 0.00 & 0.00 & 0.00 & 39.72 & 32.56 & 40.43 & 34.92 \\
\hline EOM $500 \mathrm{ml} / \mathrm{l}$ & 2.54 & 2.31 & 7.20 & 6.58 & 30.53 & 27.76 & 0.00 & 0.04 & 0.00 & 0.00 & 30.26 & 29.07 & 38.49 & 25.51 \\
\hline EOM $750 \mathrm{ml} / \mathrm{l}$ & 2.47 & 2.34 & 7.35 & 7.13 & 30.50 & 29.30 & 0.02 & 0.04 & 0.00 & 0.00 & 28.51 & 29.17 & 29.32 & 25.73 \\
\hline \multicolumn{15}{|c|}{ Source of variation ( $p$ values) } \\
\hline Diet & 0.00 & & 0.01 & & 0.00 & & 0.10 & & 0.00 & & 0.00 & & 0.00 & \\
\hline Temperature & 0.01 & & 0.01 & & 0.00 & & 0.14 & & 0.00 & & 0.60 & & 0.01 & \\
\hline Temperature $\mathrm{x}$ Diet & 0.83 & & 0.66 & & 0.63 & & 0.44 & & 0.00 & & 0.67 & & 0.02 & \\
\hline \multicolumn{15}{|c|}{ Main effect means diet } \\
\hline Control & $2.75^{a}$ & & $7.58^{\mathrm{a}}$ & & $34.18^{a}$ & & 0.00 & & 0.00 & & $6.33^{b}$ & & $305.22^{\mathrm{a}}$ & \\
\hline EOM $250 \mathrm{ml} / \mathrm{l}$ & $2.59^{a b}$ & & $7.00^{b}$ & & $31.09^{b}$ & & 0.00 & & 0.00 & & $36.14^{\mathrm{a}}$ & & $37.67^{b}$ & \\
\hline EOM $500 \mathrm{ml} / \mathrm{l}$ & $2.43^{b c}$ & & $6.88^{b}$ & & $29.15^{c}$ & & 0.02 & & 0.00 & & $29.66^{a}$ & & $32.00^{b}$ & \\
\hline EOM $750 \mathrm{ml} / \mathrm{l}$ & $2.40^{c}$ & & $7.24^{\mathrm{ab}}$ & & $29.90^{\mathrm{cb}}$ & & 0.03 & & 0.00 & & $28.84^{a}$ & & $27.52^{b}$ & \\
\hline \multicolumn{15}{|l|}{ Temperature } \\
\hline $22^{\circ} \mathrm{C}$ & 2.64 & & 7.38 & & 32.26 & & 0.01 & & 0.00 & & 25.96 & & 110.73 & \\
\hline $36^{\circ} \mathrm{C}$ & 2.45 & & 6.97 & & 29.89 & & 0.02 & & 0.00 & & 24.53 & & 90.48 & \\
\hline SEM & 0.04 & & 0.09 & & 0.45 & & 0.01 & & 0.00 & & 1.90 & & 4.71 & \\
\hline
\end{tabular}

a,b,c: Means with the same letters in a column are statistically equal ( $p>0.05)$. Red Blood Cell (RBC), Hemoglobin (HGB), Hematokrit (HCT), Nucleated red blood cells (NRBC), Nötrofil (NEUT), lymphocytes (LYMPH). 
Table 4 - The effects of EOM added to the drinking water of groups fed in stress conditions on hematologic blood parameters.

\begin{tabular}{|c|c|c|c|c|c|c|c|c|c|c|c|c|c|c|}
\hline & \multicolumn{2}{|c|}{ MCV } & \multicolumn{2}{|c|}{$\mathrm{MCH}$} & \multicolumn{2}{|c|}{$\mathrm{MCHC}$} & \multicolumn{2}{|c|}{ EO } & \multicolumn{2}{|c|}{ BASO } & \multicolumn{2}{|c|}{ IG } & \multicolumn{2}{|c|}{ MONO } \\
\hline & $22^{\circ} \mathrm{C}$ & $36^{\circ} \mathrm{C}$ & $22{ }^{\circ} \mathrm{C}$ & $36^{\circ} \mathrm{C}$ & $22^{\circ} \mathrm{C}$ & $36^{\circ} \mathrm{C}$ & $22^{\circ} \mathrm{C}$ & $36^{\circ} \mathrm{C}$ & $22^{\circ} \mathrm{C}$ & $36^{\circ} \mathrm{C}$ & $22^{\circ} \mathrm{C}$ & $36^{\circ} \mathrm{C}$ & $22^{\circ} \mathrm{C}$ & $36^{\circ} \mathrm{C}$ \\
\hline Control & 124.70 & 122.60 & 27.33 & 27.65 & 21.76 & 22.50 & 0.01 & 0.29 & 0.10 & 0.20 & 0.19 & 0.14 & 0.22 & 0.12 \\
\hline EOM $250 \mathrm{ml} / \mathrm{l}$ & 120.80 & 118.55 & 26.90 & 27.0 & 22.30 & 22.80 & 0.26 & 0.02 & 0.17 & 0.04 & 4.52 & 3.02 & 0.29 & 0.31 \\
\hline EOM $500 \mathrm{ml} / \mathrm{l}$ & 120.03 & 119.30 & 28.30 & 29.06 & 23.63 & 24.36 & 0.00 & 0.00 & 0.07 & 0.04 & 3.18 & 2.09 & 0.20 & 0.39 \\
\hline EOM $750 \mathrm{ml} / \mathrm{l}$ & 122.43 & 125.03 & 29.48 & 30.33 & 24.12 & 24.20 & 0.00 & 0.13 & 0.07 & 0.20 & 3.36 & 3.83 & 0.17 & 0.18 \\
\hline \multicolumn{15}{|c|}{ Source of variation ( $p$ values) } \\
\hline Diet & \multicolumn{2}{|c|}{0.02} & \multicolumn{2}{|c|}{0.02} & \multicolumn{2}{|c|}{0.00} & \multicolumn{2}{|c|}{0.67} & \multicolumn{2}{|c|}{0.15} & \multicolumn{2}{|c|}{0.01} & \multicolumn{2}{|c|}{0.35} \\
\hline Temperature & \multicolumn{2}{|c|}{0.59} & \multicolumn{2}{|c|}{0.43} & \multicolumn{2}{|c|}{0.20} & \multicolumn{2}{|c|}{0.67} & \multicolumn{2}{|c|}{0.61} & \multicolumn{2}{|c|}{0.48} & \multicolumn{2}{|c|}{0.71} \\
\hline Temperature $\mathrm{x}$ Diet & \multicolumn{2}{|c|}{0.42} & \multicolumn{2}{|c|}{0.97} & \multicolumn{2}{|c|}{0.91} & \multicolumn{2}{|c|}{0.31} & \multicolumn{2}{|c|}{0.03} & \multicolumn{2}{|c|}{0.79} & \multicolumn{2}{|c|}{0.50} \\
\hline \multicolumn{15}{|c|}{ Main effect means diet } \\
\hline Control & \multicolumn{2}{|c|}{$123.65^{a}$} & \multicolumn{2}{|c|}{$27.49^{b}$} & & & & & & & & & & 17 \\
\hline EOM $250 \mathrm{ml} / \mathrm{l}$ & 119 & $67^{b}$ & 26 & $95^{b}$ & & & & & & & & & & 30 \\
\hline EOM $500 \mathrm{ml} / \mathrm{l}$ & 110 & $66^{b}$ & 28. & $58^{\mathrm{ab}}$ & & & & & & & & & & 29 \\
\hline EOM $750 \mathrm{ml} / \mathrm{l}$ & 123 & $.73^{\mathrm{a}}$ & 29 & $90^{\mathrm{a}}$ & & & & & & & & & & 17 \\
\hline Temperature & & & & & & & & & & & & & & \\
\hline $22^{\circ} \mathrm{C}$ & 12 & .99 & & 0 & & & & & & & & & & 22 \\
\hline $36^{\circ} \mathrm{C}$ & 12 & .37 & 28 & 51 & & & & & & & & & & 24 \\
\hline SEM & 0 & & 0. & 45 & & & & & & & & & & 04 \\
\hline
\end{tabular}

$a, b, c:$ Means with the same letters in a column are statistically equal ( $p>0.05)$. Mean Cell Volume(MCV), Mean Cell Hemoglobin (MCH), Mean Cell Hemoglobin Concentration (MCHC), eosinophils (EO), immunoglobulin (IG).

\section{DISCUSSION}

With oxidative stress and increased activity of Reactive oxygen species (ROS), contractile proteins under gochemical oxidation, resulting in changes in their structural conformation or functional activity (Steinberg, 2013). Cardiac troponin I (cTnl) is a specific protein that binds to filaments in the cardiomyocyte sarcoma and affects the contraction of the heart muscle via calcium metabolism. cTnl only increases the amount of blood due to damaged myocardial tissue and cells and is normally not in the blood of healthy individuals. For this reason, in recent years, such as myocardial infarction, heart origin diseases have gained important diagnosis (Maxwell et al., 1997; Fridén et al., 2017). In our study, the effects of different concentrations of EOM added to broilers' drinking water fed in an environment of heat stress on cTnl were investigated on. Studies have shown that cardiac troponin $\mathrm{T}$ ( $\mathrm{CTnT}$ ) increases as a result of occlusive stress compared to healthy birds (Aksit et al., 2008). Cardiac troponin T was an indicator of early cardiac damage before clinical manifestations. In another study, a higher value of troponin-T was determined as a result of stress caused by temperature differences (Maxwell, 1994; Maxwell et al., 1995; Maxwell et al., 1997; Aksit et al., 2008). A similar study on broilers showed that heat stress had a negative effect on specific myofibrillar fragments, which affected the level of troponin (Santos et al., 2008), heat stress applied to broiler stress and heart values have been determined to increase (Tekce \& Gül, 2017). In our study, levels of cTnl were higherin the EOMtreated groups than in the control group, in groups not exposed to temperature stress $\left(22^{\circ} \mathrm{C}\right)$. However, in the groups exposed to temperature stress $\left(36^{\circ} \mathrm{C}\right)$, there was no effect on $\mathrm{cTnl}(p<0.05)$. Our results seem consistent with those in published literature.

Blood parameters vary depending on the health, environmental conditions, and dietary preferences (Gümüş \& Imik, 2016). In addition to these factors, the additives that are involved in the feed and the blood values of the organism vary depending on the oxidative stress. Depending on the oxidative stress, analysis of blood samples taken on the $42^{\text {nd }}$ day showed an increase in haematological values, and cultivation in high-stress environmental conditions had a marked negative effect on the blood parameters (Nezhad \& Shahryar, 2011; Mahmoud et al., 2011; 2013). However, in another similar study where the essential oil was added to the broiler ration under temperature stress showed no effect on haematological values (Demir et al., 2008; Toghyani et al., 2010; Hong et al., 2012; Tekce \& Rose, 2017). In the present study, we found that there was no significant difference between the groups WBC, RBC, HGB, HCT, RDW-SD, RDW-CV and Lymphocyte compared to the groups WBC, nut and IG, and it had no effect on CK, creatine, MCV, $\mathrm{MCH}$, mono, EO and Baso in the groups that were not subjected to temperature stress $\left(22^{\circ} \mathrm{C}\right)$. In groups 
exposed to temperature stress (36 OC), WBC, HGB, HCT, RDW-SD and LMYPH decreased compared to the control group, increased compared to $\mathrm{MCH}, \mathrm{MCHC}$, neut and IG, but had no effect on $C K$, creatine, RBC, RDW-CD, mono, EO and Baso $(p<0.05)$. While some of the studies that we have been in compliance within the literature (Demir et al., 2008; Toghyani et al. , 2010; Hong et al., 2012; Tekce \& Gül, 2017), some literature information are incompatible with the data (Nezhad \& Shahryar, 2011; Mahmoud et al., 2013). Discrepancies in study results are likely attributed to the manner of joining broiler rations, the dosages, and the difference in the contents of the EOM.

In conclusion, the EOM mixture did not have any effect on cardiac troponin I(cTnl) and haematocrit values. Further studies are required to better understand the addition of EOM to broiler drinking water.

\section{ACKNOWLEDGMENTS}

This study was funded and supported by the scientific research projects commission of Bayburt University, Bayburt, Turkey (Project code: 2017/0269001-01).

\section{REFERENCES}

Aksit M, Altan O, Buyukozturk A, Balkaya M, Ozdemir D. Effects of cold temperature and vitamin $\mathrm{E}$ supplementation on oxidative stress, Troponin-T level and other ascites related traits in broilers. Archiv für Geflügelkunde/European Poultry Science 2008;72(5):221.

Al-Ja'fari AH, Vila R, Freixa B, Tomi F, Casanova J, Costa J, et al. Composition and antifungal activity of the essential oil from the rhizome and roots of Ferula hermonis. Phytochemistry 2011;72(11-12):1406-1413.

Alpert J, Thygesen K, Antman E, Bassand J. Myocardial infarction redefined-a consensus document of the Joint European Society of Cardiology/American College of Cardiology Committee for the redefinition of myocardial infarction. Journal of the American College of Cardiology 2000;36(3):959-969.

AOAC - Association of Official Analytical Chemists. Official methods of analysis of AOAC international. 18 ${ }^{\text {th }}$ ed. Rockville; 2005.

Botsoglou N, Christaki E, Florou-Paneri P, Giannenas I, Papageorgiou G, Spais A. The effect of a mixture of herbal essential oils or á-tocopheryl acetate on performance parameters and oxidation of body lipid in broilers. South African Journal of Animal Science 2004; 34(1):52-61.

Breeding S, McRee W, Ficken M, Ferket P. Effect of protein restriction during brooding on spontaneous turkey cardiomyopathy. Avian Diseases 1994;38(2):366-370.

Burt S. Essential oils: their antibacterial properties and potential applications in foods-a review. International Journal of Food Microbiology 2004;94(3):223-253

ÇETIN M. The use of plant extracts and artemisia absinthium as alternative to antibiotics and antihelmintics inanimal nutrition. KSU Journal of Natural Science 2012;15(4):58-63.
Daroui-Mokaddem H, Kabouche A, Bouacha M, Soumati B, El-Azzouny A, Bruneau $C$, et al. GC/MS analysis and antimicrobial activity of the essential oil of fresh leaves of Eucalytus globulus, and leaves and stems of Smyrnium olusatrum from Constantine (Algeria). Natural product communications 2010;35(10):1669-1672.

Demir E, Kilinc K, Yildirim Y, Dincer F, Eseceli H. Comparative effects of mint, sage, thyme and flavomycin in wheat-based broiler diets. Archiva Zootechnica 2008;11(3):54-63.

Dezsi Ș, Bădărău AS, Bischin C, Vodnar DC, Silaghi-Dumitrescu R, Gheldiu $A M$, et al. Antimicrobial and antioxidant activities and phenolic profile of Eucalyptus globulus Labill. and Corymbia ficifolia (F. Muell.) KD Hill \& LAS Johnson leaves. Molecules 2015;20(3):4720-4734.

England J, Loughna S, Rutland C. Multiple species comparison of cardiac troponin $\mathrm{T}$ and dystrophin: unravelling the DNA behind dilated cardiomyopathy. Journal of Cardiovascular Development and Disease $2017 ; 4(3): 8$

Feizi A, Bijanzad P, Kaboli, K. Effects of thyme volatile oils on performance of broiler chickens. European Journal of Experimental Bioliology 2013;3:250-254.

Ferrucci L, Guralnik JM, Woodman RC, Bandinelli S, Lauretani F, Corsi AM, et al. Proinflammatory state and circulating erythropoietin in persons with and without anemia. The American Journal of Medicine 2005;118(11):e1211-1288

Fridén V, Starnberg K, Muslimovic A, Ricksten SE, Bjurman C, Forsgard N, et al. Clearance of cardiac troponin $T$ with and without kidney function. Clinical Biochemistry 2017;50(9):468-474.

Guimarães AG, Quintans JS, Quintans-Júnior LJ. Monoterpenes with analgesic activity - a systematic review. Phytotherapy Research 2013:27(1):1-15.

Gümüș R, Imik H. The effect of Yucca schidigera powder added to lamb feed on fattening performance, some blood parameters, the immune system, and theantioxidative metabolism of the hepatic tissue. Turkish Journal of Veterinary and Animal Sciences 2016;40(3):263-270.

Habrun B, Simpraga B, Kompes G, Krstulovic F. Antimicrobial resistance and serotyping of Salmonella enteric subsp. enterica isolated from poultry in Croatia. Veterinarski Arhiv 2012; 4(82):371-381.

Hong JC, Steiner T, Aufy A, Lien TF. Effects of supplemental essential oil on growth performance, lipid metabolites and immunity, intestinal characteristics, microbiota and carcass traits in broilers. Livestock Science 2012;144(3):253-262.

Kamely M, Torshizi MAK, Wideman RF, West J. Upregulation of SERT and ADORA1 in broilers with acute right ventricular failure. Research in Veterinary Science 2019;125: 397-400.

Kpoviessi S, Bero J, Agbani P, Gbaguidi F, Kpadonou-Kpoviessi B, Sinsin B et al. Chemical composition, cytotoxicity and in vitro antitrypanosomal and antiplasmodial activity of the essential oils of four Cymbopogon species from Benin. Journal of Ethnopharmacology 2014; 151(1):652659.

Kusumoto A, Miyata M, Kubozono T, Ikeda Y, Shinsato T, Kuwahata S, et al. Highly sensitive cardiac troponin $T$ in heart failure: comparison with echocardiographic parameters and natriuretic peptides. Journal of Cardiology 2012;59(2):202-208.

Mahmoud UT, Abdel-Rahman MA, Darwish MHA, Mosaad GM. The effect of heat stress on blood picture of japanese quail. Journal of Advanced Veterinary Research 2013;3(2):69-76.

Mahmoud UT, Abdel-Rahman MAM, Darwish MHA, Applegate TJ, Cheng HW. Behavioral changes and feathering score in heat stressed broiler chickens fed diets containing different levels of propolis. Applied Animal Behaviour Science 2015;166:98-105 
Maron BJ, Towbin JA, Thiene G, Antzelevitch C, Corrado D, Arnett D, et al. Contemporary definitions and classification of the cardiomyopathies: an American Heart Association scientific statement from the council on clinical cardiology, heart failure and transplantation committee; quality of care and outcomes research and functional genomics and translational biology interdisciplinary working groups; and council on epidemiology and prevention. Circulation 2006;113(14):1807-1816.

Maxwell M, Robertson G, Moseley D, Bautista-Ortega J. Characterisation of embryonic cardiac-derived troponin T in broiler chicks bled one to 168 hours after hatching. Research in Veterinary Science 1997;62(2):127130.

Maxwell M, Robertson G, Moseley D. Serum troponin T values in 7-day-old hypoxia-and hyperoxia-treated, and 10-day-old ascitic and debilitated, commercial broiler chicks. Avian Pathology 1995;24(2):333-346.

Maxwell MH, Robertson GW, Moseley D. Po-tential role of serum troponin $\mathrm{T}$ in cardiomyocyte injuryin the broiler ascites syndrome. British Poultry Science 1994;35:663-667.

Metivier F, Marchais SJ, Guerin AP, Pannier B, London GM. Pathophysiology of anaemia: focus on the heart and blood vessels. Nephrology Dialysis Transplantation 2000;15(3):14-18.

Mohamed EA, Ali OH, Malik E, Yousif I. Effect of season and dietary protein level on some haematological parameters and blood biochemical compositions of three broiler strains. International Journal of Poultry Science 2012;11(12):787.

Monzote L, Garcia M, Montalvo A, Scull R, Miranda M, Abreu, J. In vitro activity of an essential oil against Leishmania donovani. Phytotherapy Research 2007;21(11):1055-1058

Muhlestein J, Lappe D, Anderson J, Muhlestein J, Budge D, May H, et al. Both initial red cell distribution width (RDW) and change in RDW during heart failure hospitalization are associated with length of hospital stay and 30-day outcomes. International Journal of Laboratory Hematology 2016;38(3):328-337.

Nezhad E, Shahryar A. The role of oxidative stress in the development of congestive heart failure (CHF) in broilers with pulmonary hypertension syndrome (PHS). Journal of Cell and Animal Biology 2011;5(8):176181.

O'Brien PJ. Cardiac troponin is the most effective translational safety biomarker for myocardial injury in cardiotoxicity. Toxicology 2008;245(3):206-218.

O'brien P, Smith D, Knechtel T, Marchak M, Pruimboom-Brees I, Brees D, et al. Cardiac troponin I is a sensitive, specific biomarker of cardiac injury in laboratory animals. Laboratory Animals 2006;40(2):153-171.

Salvagno GL, Sanchis-Gomar F, Picanza A, Lippi G. Red blood cell distribution width: A simple parameter with multiple clinical applications. Critical Reviews in Clinical Laboratory Sciences 2015;52(2):86-105.

Santos CDC, Delgado EF, Menten JFM, Pedreira ACDM, Castillo CJC, Mourão GB, et al. Sarcoplasmatic and myofibrillar protein changes caused by acute heat stress in broiler chicken. Scientia Agricola 2008;65(5):453-458
Saravanan G, Ponmurugan P, Sathiyavathi M, Vadivukkarasi S, Sengottuvelu S. Cardioprotective activity of Amaranthus viridis Linn: effect on serum marker enzymes, cardiac troponin and antioxidant system in experimental myocardial infarcted rats. International Journal of Cardiology 2013;165(3):494-498

Sato Y, Fujiwara H, Takatsu Y. Biochemical markers in heart failure. Journal of Cardiology, 2012;59(1):1-7.

Silva C, Moura F, Mendes M, Pessoa F. Extraction of citronella (Cymbopogon nardus) essential oil using supercritical CO2: Experimental data and mathematical modeling. Brazilian Journal of Chemical Engineering $2011 ; 28(2): 343-350$.

Steinberg SF. Oxidative stress and sarcomeric proteins. Circulation Research 2013; $112(2): 393-405$.

Summers JD, Adams CA, Lesson S. Metabolic disorders in poultry. Leicestershire: Context Products; 2013.

Tang S, Buriro R, Liu Z, Zhang M, Ali I, Adam A, et al. Localization and expression of $\mathrm{Hsp} 27$ and $\alpha \mathrm{B}$-crystallin in rat primary myocardial cells during heat stress in vitro. PloSone 2013;8(7):e69066.

Tekce E, Gül M. Effects of Origanum Syriacum Essential Oil on Blood Parameters of Broilers Reared at High Ambient Heat. Revista Brasileira de Ciência Avícola 2017;19(4):655-662.

Tekce E, Mehmet G. Usege of essential fatty acids in broiler feeds area. Gümüşhane University Journal of the Institute of Science and Technology 2016;6(2):74-88

Toghyani M, Tohidi M, Gheisari AA, Tabeidian SA. Performance, immunity, serum biochemical and hematological parameters in broiler chicks fed dietary thyme as alternative for an antibiotic growth promoter. African Journal of Biotechnology 2010;39(40):6819-6825

Wexler R, Elton T, Pleister A, Feldman D. Cardiomyopathy: an overview. American Family Physician 2009;79(9):778

Wieczorek DF, Jagatheesan G, Rajan S. The role of tropomyosin in heart disease. In: Gunning P, editor. The role of tropomyosin in heart disease. New York: Springer; 2008. p.132-142.

Wu D, Xu J, Song E, Tang S, Zhang X, Kemper N, et al. Acetyl salicylic acid protected against heat stress damage in chicken myocardial cells and may associate with induced Hsp27 expression. Cell Stress and Chaperones 2015;20(4):687-696.

Yörük MA, Laçin E, Hayirli A, Yildiz A. The effects of humate and prebiotic supplementation on laying performance, egg quality and blood parameters of Japenese quails reared in different cage densities. YYÜ Journal of the Faculty of Veterinary Medicine 2008; 19(1):15-22. 
